\title{
Influence of Early and Prolonged Protein Depletion in the Diet on in vitro Protein Synthesis in Muscle and Liver of Rats
}

\author{
Akihiko Goto and Masao KametaKa \\ Department of Agricultural Chemistry, Faculty of Agriculture, \\ The University of Tokyo, Tokyo \\ Received September 17, 1973
}

\begin{abstract}
Male rats weighing about $200 \mathrm{~g}$ were killed after $1,2,4,10$, and 20 days on a protein-free diet, and in vitro synthesis of protein was measured by the incorporation of ${ }^{14} \mathrm{C}$-glycine into protein of liver slices and isolated soleus muscle. The incorporation value was corrected for the differences in specific radioactivity of intracellular free glycine, and protein and RNA contents of tissue were determined.

Muscle protein synthesis began to decrease from the 1st day of depletion, fell rapidly until the 4 th day, and then was reduced gradually to about $30 \%$ of the initial control by the 20th day. This reduction was due in a major part to a fall in the rate of protein synthesis per unit of RNA and in a minor part to a decline in RNA content. In the liver, protein synthesis increased in the early period of protein depletion, but declined with prolonged depletion, and was reduced greatly by severe depletion. These alterations were caused mainly by the changes in incorporative activity per unit of RNA.

From these results, it was suggested that different patterns of adaptive response to protein depletion occurred in both cases of early and prolonged depletion in connection with protein metabolism in rats.
\end{abstract}

Although the effect of diet protein content on protein turnover in tissues has been investigated in vivo, ${ }^{1 \sim 9)}$ there is little accurate information available. If synthesis rates are measured from the extent of incorporation of a labeled amino acid into protein after a single injection of the amino acid, information must be obtained concerning the specific activity of the precursor amino acid and its variation with time. When calculations of turnover rate are made from the decay curve in the specific activity of incorporated label into protein after injection of a labeled amino acid, a labeled material which is not re-utilized must be used. Therefore, the constant infusion method in which the specific activity of amino acid is kept constant and the use of guanidino- ${ }^{14} \mathrm{C}$ arginine which is known to be re-utilized less, have been devised. However, the results obtained are conflicting, especially in the case of the liver. On the other hand, the results in in vitro studies also show defferences in several works concerning protein synthesis of the liver in a cell-free system. ${ }^{10 \sim 15)}$ Very few in- vestigations have been carried out concerning protein synthesis in muscle in spite of its importance because of the larger amount of muscle protein in the body. ${ }^{16,17}$ )

In this paper, the influence of dietary protein deficiency on tissue protein synthesis in rats was studied in vitro by incorporation of ${ }^{14} \mathrm{C}$ glycine into protein of isolated soleus muscle and liver slices. Incorporation value were corrected for differences in the specific radioactivity of intracellular free glycine. At the same time, protein and ribonucleic acid (RNA) contents of the tissue were measured. This in vitro system has the following features: 1) The incorporation rate of radioactivity in protein shows the protein synthesis capacity of the tissue as an integration of many factors such as ribosome content, ribosome activity and related enzyme activity, and the incorporation value per unit of RNA reflects the ribosome activity in the intact cell; 2) protein synthesis activity at this level is considered to be close to in vivo activity in the tissue, and to be far higher than in a cell-free system in which the 
activity is known to be much less than in an in vivo system; 3) in this system, correction of the isotope incorporation for differences in the specific radioactivity of free amino acid is more accurate than in the in vivo system since the specific activity of intracellular labeled amino acid is relatively constant during the incubation unlike in in vivo experiments.

The results of this study showed that protein synthesis in muscle decreased remarkably and quickly by feeding a protein-free diet, and that liver protein synthesis increased early in protein deficiency but was reduced with prolonged deficiency. These alterations in protein synthesis were largely attributed to the changes in the protein synthesis per unit of RNA.

\section{MATERIALS AND METHODS}

Animals and diets: Male rats of the Wistar strain weighing about $150 \mathrm{~g}$ were kept in individual cages in a room with a temperature of $22 \pm 1^{\circ} \mathrm{C}$, humidity of 55 to $60 \%$, and a 6 am to $6 \mathrm{pm}$ light cycle. The composition of diets is given in Table I. The protein-free

Table I. Composition of Diets $(\%)$

\begin{tabular}{lcc}
\multicolumn{1}{c}{ Diet } & Normal & Protein-free \\
\hline Corn starch & 65 & 85 \\
Casein & 20 & 0 \\
Soybean oil & 5 & 5 \\
Cellulose powder $^{\prime}$ & 5 & 5 \\
Salt mixture $^{a)}$ & 4 & 4 \\
Vitamin mixture $^{b}$, & 1 & 1 \\
\hline
\end{tabular}

a) Tanabe Amino Acid Research Foundation.

b) Contents per $100 \mathrm{~g}$ of diet; vitamin mix. (Tanabe Amino Acid Research Foundation) $0.85 \mathrm{~g}$, choline chloride 0.15 g, V.A. 300 IU, V.D. 100 IU, V.E. $5 \mathrm{mg}$.

diet was prepared by replacing casein in the normal diet $(20 \%$ casein) with starch. Food and water were given ad libitum. After prefeeding with the normal diet, rats weighing about $200 \mathrm{~g}$ were divided into 7 groups of 4 to 5 rats each. As control groups, a group of rats was killed at the beginning of the study and another was killed after 12 days on the normal diet. Experimental groups of rats fed the protein-free diet were killed after 1,2, 4, 10, and 20 days. All rats were killed at $1 \mathrm{pm}$ without previous fasting by decapitation and exsanguination under ether anesthesia.

Incubation of tissue: Paired soleus muscle $(M$. soleus, $50 \sim 90 \mathrm{mg} /$ muscle) were excised from the hind limbs by cutting the tendons, cafe being taken not to damage the fibers. One muscle was used for incubation and another for determination of RNA and protein. Slices were prepared by the free-hand method of Isaka and Shibata, ${ }^{18)}$ from the same positions in the livers, and those from the outer layers were not used. A muscle or two liver slices $(0.5 \mathrm{~mm}$ thick, totalling about $100 \mathrm{mg}$ in weight) were placed in a $10 \mathrm{ml}$ conical flask containing $2.0 \mathrm{ml}$ of Krebs-Ringer phosphate buffer ( $\mathrm{pH} 7.4)^{191}$ and gassed with $\mathrm{O}_{2}$. The buffer contained $0.2 \mu \mathrm{Ci} / \mathrm{ml}$ of ${ }^{14} \mathrm{C}$-glycine (U) $(99.7 \mathrm{mCi} /$ mmole) and $4 \mathrm{~mm}$ of an equimolar mixture of 20 amino acids. All the above procedures were performed at $4^{\circ} \mathrm{C}$. The incubation was carried out at $37^{\circ} \mathrm{C}$ in a water bath shaken at 70 cycles/min for $2 \mathrm{hr}$ and $15 \mathrm{~min}$ and $4 \mathrm{hr}$ and $15 \mathrm{~min}$ for muscle and liver slices, respectively. Incorporation values were obtained by subtracting the value of incubation for $15 \mathrm{~min}$, since the intracellular free radioactivity reached a constant value after incubation for $15 \mathrm{~min}$. It was shown in the previous report, ${ }^{201}$ that incorporation in muscle and liver slices increased lineary for at least 2 and $4 \mathrm{hr}$ respectively and that the total incorporation was in proportion to the weight of incubated tissue up to $200 \mathrm{mg}$.

Incorporation of ${ }^{14} \mathrm{C}$-glycine in tissue protein: After incubation, the tissue was washed quickly twice with the cold buffer, plunged into $5 \%$ trichloroacetic acid (TCA) and ground in a Teflon-glass Potter-Elvehjem homogenizer. The homogenate was then poured into centrifuge tubes and spun for $10 \mathrm{~min}$ at $1000 \times \mathrm{g}$. The combined supernatant and washings were gathered for each group and used for the determination of specific radioactivity of intracellular free glycine. The resulting insoluble fraction was washed twice with $5 \% \mathrm{TCA}$, heated in $5 \% \mathrm{TCA}$ at $95^{\circ} \mathrm{C}$ for $15 \mathrm{~min}$ to extract nucleic acid and washed twice with ethanol-ether $(3: 1)$. The residue protein was dissolved in formic acid and $6 \sim 8$ $\mathrm{mg}$ was plated on planchettes, dried under an infrared lamp and assayed for radioactivity in a gas-flow counter. The assay was performed without selfabsorption and the sample weight was regarded as the protein weight. Glycine incorporated in tissue protein and the incorporative activity per unit of RNA were calculated using the following formulae:

$$
\begin{aligned}
& \text { Glycine incorporation (B) (m } / \text { moles/mg protein) } \\
& \text { radioactivity incorporated }(\mathrm{A})(\mathrm{cpm} / \mathrm{mg} \text { protein) } \\
& =\overline{\text { specific radioactivity of intracellular free glycine }} \\
& \text { ( } \mathrm{cpm} / \mathrm{m} \mu \mathrm{mole})
\end{aligned}
$$

Incorporative activity per unit of RNA (C) (m $\mu$ moles/ $\mu$ gRNA)

glycine incorporation (B) ( $\mathrm{m} \mu$ moles/mg protein)

$=$ ratio of RNA to protein content of tissue ( $\mu \mathrm{gRNA} / \mathrm{mg}$ protein)

Concentration and specific radioactivity of intra- 
cellular free glycine: The supernatants from each homogenate were pooled for each group and $1 \%$ picric acid was added after TCA was extracted twice with equal volumes of ether. After centrifugation the supernatant was passed through a Dowex $1 \times 8(\mathrm{Cl}$ type $)$ column to remove the picric acid. The eluates were dried under reduced pressure in a rotary evaporator and the residue was dissolved in citric acid buffer ( $\mathrm{pH}$ 2.2). Part of this was applied to the amino acid analyzer (Shibata) for glycine determination. With another part, radioactivity of ${ }^{14} \mathrm{C}$-glycine was estimated by collecting the glycine portion of the eluate from the column of the analyzer and counting in a gas-flow counter. Intracellular concentration of glycine and ${ }^{14} \mathrm{C}$-glycine radioactivity were calculated from the formula of Kipnis and Cori, ${ }^{211}$ using the distribution ratios of intracellular and extracellular pools in tissue water which were obtained by Hider et al. ${ }^{22}$ and Mortimore and Mondon.23) The value of specific radioactivity was obtained from these values. The distribution of ${ }^{14} \mathrm{C}$-glycine in the total ${ }^{14} \mathrm{C}$ of the TCAsoluble fraction of the tissue after incubation was $90 \sim$ $100 \%$ in the soleus muscle but $55 \sim 80 \%$ in liver slices. It was already shown in the previous report ${ }^{24}$ that ${ }^{14} \mathrm{C}$-glycine comprised $85 \%$ of the total free ${ }^{14} \mathrm{C}$-amino acids in liver slices no matter whether animals were fed the protein-free diet or the normal diet.

Determination of RNA and protein: Whole soleus muscle or a portion of the liver was homogenized with ice-cold $10 \%$ TCA in a Teflon-glass Potter-Elvehjem homogenizer. After the precipitate was washed with cold $10 \%$ TCA, and lipid was extracted with hot ethanol-ether (3:1), RNA was extracted with $5 \%$ TCA at $90^{\circ} \mathrm{C}$ for $15 \mathrm{~min}$ according to Schneider's method. ${ }^{25}$ The extracted RNA was determined by the orcinol reaction method of Kerr and Seraidarian ${ }^{26}$ ) and the dried protein residue was weighed.

\section{RESULTS}

Body and tissue weights, and protein and RNA contents of tissues: Body weights changed as shown in Fig. 1. Tissue weights (A), protein content (B), RNA content (C) and ratio of RNA to protein (D) are shown in Fig. 2 for soleus muscle and Fig. 3 for liver. Tissue weights and contents of protein and RNA were expressed per $100 \mathrm{~g}$ of initial body weight (I.B.W.). Protein contents of both soleus muscle and liver decreased sharply in the early stages of protein deficiency. Soleus muscle lost about 15 and $20 \%$ of the initial control protein on the 1st and 4th day respectively, and thereafter continued to lose slightly. The

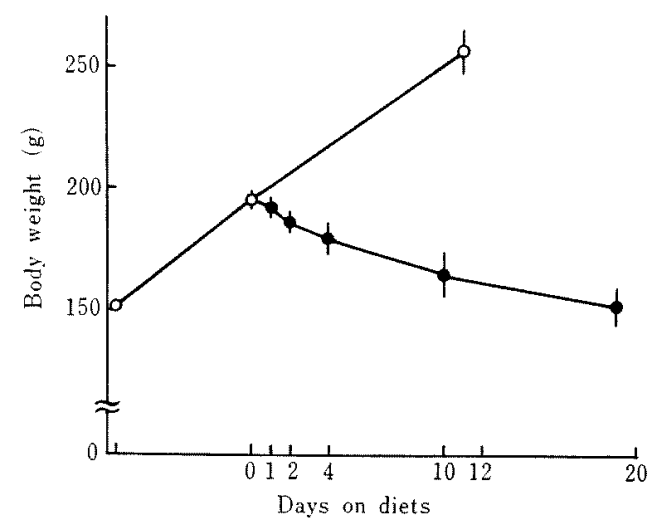

FIG. 1. Change in the Body Weight of Rats Fed the Normal $(O)$ or Protein-free Diet ( $)$.

The vertical bars indicate standard errors of the means.

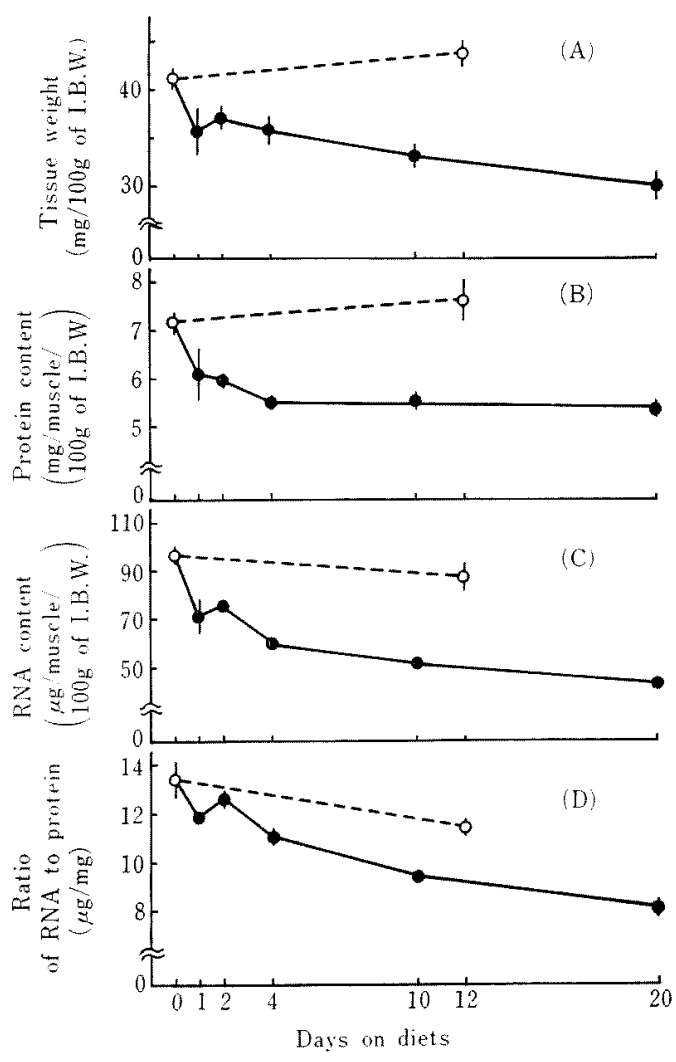

FIG. 2. Weight (A), Protein (B) and RNA (C) Contents, and Ratio of RNA to Protein (D) of Soleus Muscle in Rats Fed the Normal (O--O) or Proteinfree Diet $(-)$ ).

Values in (A), (B) and (C) are per $100 \mathrm{~g}$ of the initial body weight (I.B.W.). Each point is the mean for 4 to 5 rats. The vertical bars indicate standard errors. 


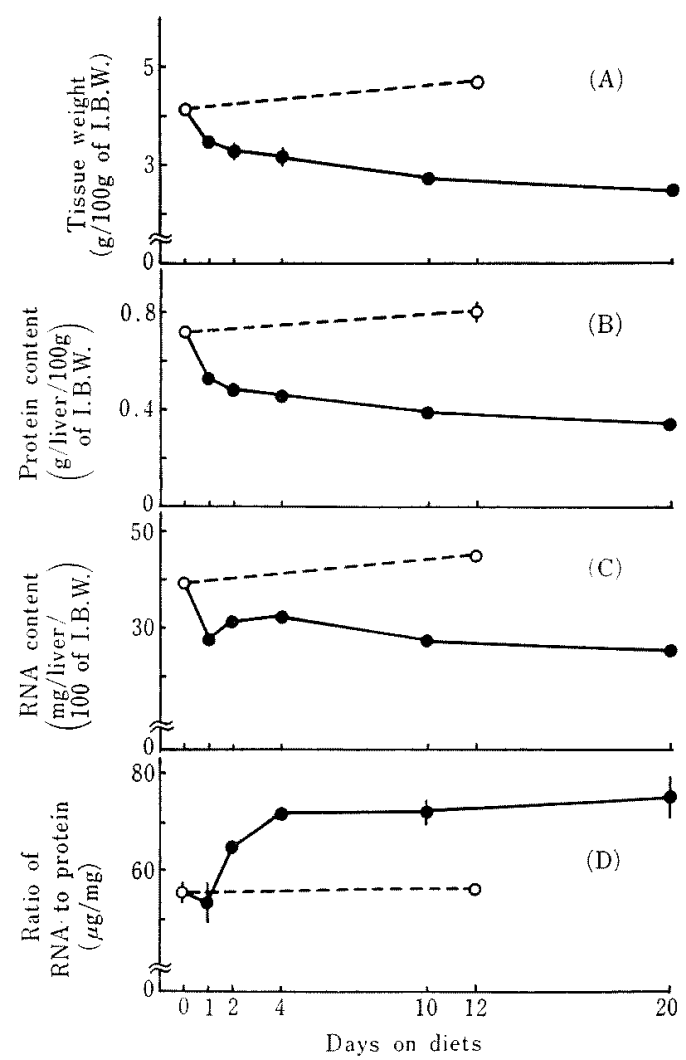

Fig. 3. Weight (A), Protein (B) and RNA (C) Contents, and Ratio of RNA to Protein (D) of Liver in Rats Fed the Normal (O--O) or Protein-free Diet $(\bullet-\bullet)$.

Values in (A), (B) and (C) are per $100 \mathrm{~g}$ of the initial body weight (I.B.W.). Each point is the mean for 4 to 5 rats. The vertical bars indicate standard errors. liver protein decreased by $30 \%$ and $40 \%$ of the control on the 1st and 4th day respectively, and then decreased gradually to less than half of the initial on the 20th day. RNA content of soleus muscle decreased rapidly in the early stage of depletion as did the protein. The muscle lost $26 \%, 37 \%$ and more than $50 \%$ of the initial amount, on the 1st, 4th, and 20th day of depletion respectively. In the liver, RNA content decreased by about $30 \%$ on the 1st day, then increased somewhat on the 2nd and 4th day, and dropped again to almost the same level as the 1st day on the 10th and 20th day.

The decrease rate of RNA content in the soleus muscle was larger than that of the protein. Consequently the ratio of RNA to protein in the tissue continued to fall from the beginning of depletion and dropped to $80 \%$ and $60 \%$ of the control on the 4 th and 20 th day respectively. However, the decrease in RNA content of the liver was not as large as the decrease in the protein content. Therefore, the ratio of RNA to protein in the liver increased by $20 \%$ on the 2 nd day and by about $30 \%$ of the initial control after the 4th day. After feeding with the normal diet for 12 days, the ratio in muscle showed a decrease of $15 \%$, whereas it did not change in the liver.

Concentration and specific radioactivity of intracellular free glycine: Table II shows the concentration and specific radioactivity of intracellular free glycine in soleus muscle and

Table II. Concentration and Specific Radioactivity of Intracellular Free Glycine in Isolated Soleus Muscle and Liver Slices after Incubation

Initial concentration and specific radioactivity of free glycine in the medium are $0.2 \mu \mathrm{moles} / \mathrm{ml} \mathrm{and}$ $142 \mathrm{cpm} / \mathrm{m} /$ mole, respectively. Each value is given from pooled samples of 4 to 5 rats.

\begin{tabular}{|c|c|c|c|c|c|}
\hline \multirow[t]{2}{*}{ Diet } & \multirow[t]{2}{*}{$\begin{array}{l}\text { Days } \\
\text { on diets }\end{array}$} & \multicolumn{2}{|c|}{$\begin{array}{c}\text { Concentration } \\
(\mu \text { moles } / \mathrm{ml})\end{array}$} & \multicolumn{2}{|c|}{$\begin{array}{c}\text { Specific } \\
\text { radioactivity } \\
(\mathrm{cpm} / \mathrm{m} / \mathrm{mole})\end{array}$} \\
\hline & & Muscle & Liver & Muscle & Liver \\
\hline Normal & $\begin{array}{r}0 \\
12\end{array}$ & $\begin{array}{l}2.21 \\
2.07\end{array}$ & $\begin{array}{l}1.05 \\
0.90\end{array}$ & $\begin{array}{l}12.9 \\
13.2\end{array}$ & $\begin{array}{l}14.3 \\
10.9\end{array}$ \\
\hline Protein-free & $\begin{array}{r}1 \\
2 \\
4 \\
10 \\
20\end{array}$ & $\begin{array}{l}1.94 \\
2.43 \\
1.93 \\
2.51 \\
1.94\end{array}$ & $\begin{array}{l}1.48 \\
1.47 \\
1.50 \\
0.97 \\
0.82\end{array}$ & $\begin{array}{l}13.7 \\
12.1 \\
15.2 \\
12.6 \\
17.7\end{array}$ & $\begin{array}{r}10.3 \\
6.6 \\
7.4 \\
7.8 \\
14.3\end{array}$ \\
\hline
\end{tabular}


liver slices after incubation. No major change was observed in glycine concentration in muscle during the protein deficiency. In the liver, glycine concentration increased during the early stages of protein depletion (on the 1st, 2 nd, and 4 th day) by $40 \%$ of the control. Among the tissue free amino acids, nonessential amino acids such as glycine generally tend to increase in concentration in the liver when animals are fed protein-free diet for several days. ${ }^{27)}$ Therefore, it was thought that glycine concentration in liver slices after incubation reflected this in the tissue of animals before being killed. The specific radioactivity of free glycine in muscle was not changed much except for a small increase on the 20th day of depletion. In liver slices, it dropped during the protein depletion except on the 20th day. In most cases, the specific radioactivity was lower when glycine concentration was higher in both tissues.

Incorporation of ${ }^{14} \mathrm{C}$-glycine into protein: Incorporation of ${ }^{14} \mathrm{C}$-glycine into tissue protein is shown in Fig. 4 for soleus muscle and Fig. 5 for liver slices. The values shown in $\mathrm{B}$ are nmoles of glycine incorporated into tissue protein which were calculated from the values in $A$ using the value of the specific radioactivity of intracellular free glycine shown in Table II. If there were a homogeneous intracellular precursor pool of amino acids for protein synthesis, the values in $\mathrm{B}$ would be the incorporation values which were corrected for the difference in specific radioactivity of tissue free glycine of each group. The values in $C$ represent the glycine incorporation per unit of RNA and this value is thought to reflect the rate of protein synthesis per unit of ribosomes in the cell since tissue RNA is preponderantly ribosomal. Incorporation of radioactivity in muscle protein began to decline rapidly from the beginning of depletion and after the 4th day it decreased gradually. Even when the incorporation value was corrected, this trend was unchanged, and the incorporation was reduced to $40 \%$ and $30 \%$ of the control on the 4 th and 20th day respectively. Incorporative activity per unit of RNA also began to decrease

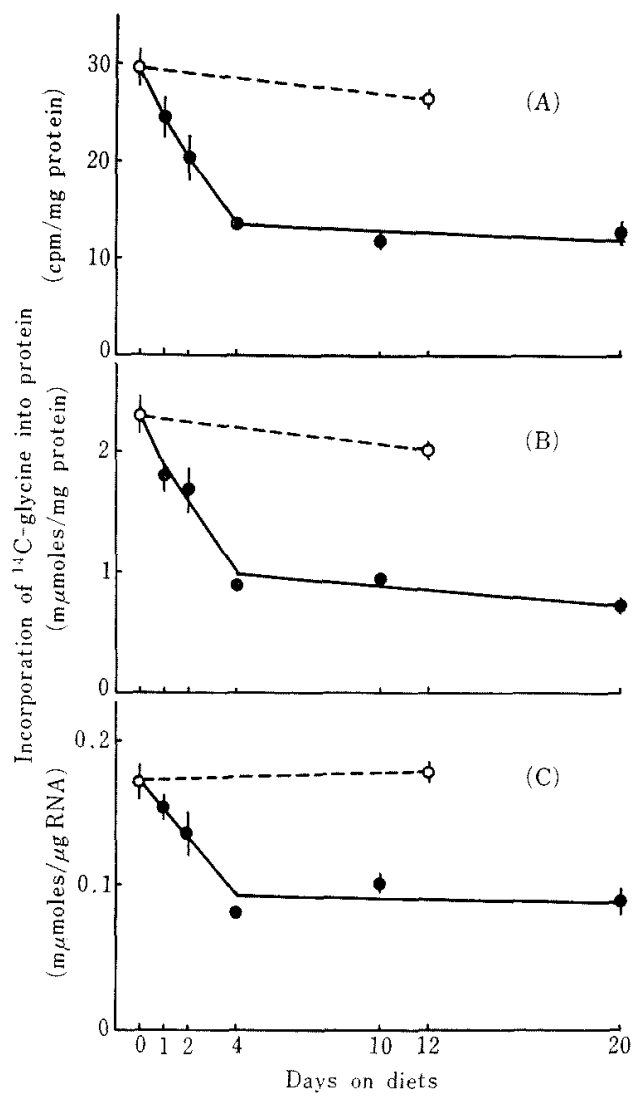

FIG. 4. Incorporation of ${ }^{14} \mathrm{C}$-Glycine into Protein from Isolated Soleus Muscle of Rats Fed the Normal (O--O) or Protein-free Diet

Values in (B) and (C) are calculated from values in (A) using the formulae shown in MATERIALS AND METHODS. Each point is the mean for 4 to 5 rats. The vertical bars indicate standard errors.

from the 1st day, and dropped to about the half of the control after the 4th day of depletion. From these results shown in Fig. $2 \mathrm{D}$ and Fig. 4 , the decrease in protein synthesis capacity of the soleus muscle is due in a major part to a fall in the synthesis rate per unit of ribosomes and in a minor part to a decline of RNA content. On the other hand, after feeding the normal diet for 12 days, protein synthesis in muscle diminished slightly, which was attributed to the decrease in RNA content of tissue with muscle growth, since the protein synthesis activity per unit of RNA was hardly changed.

Incorporation of radioactivity in liver protein increased by $30 \%$ on the 1st day and after- 


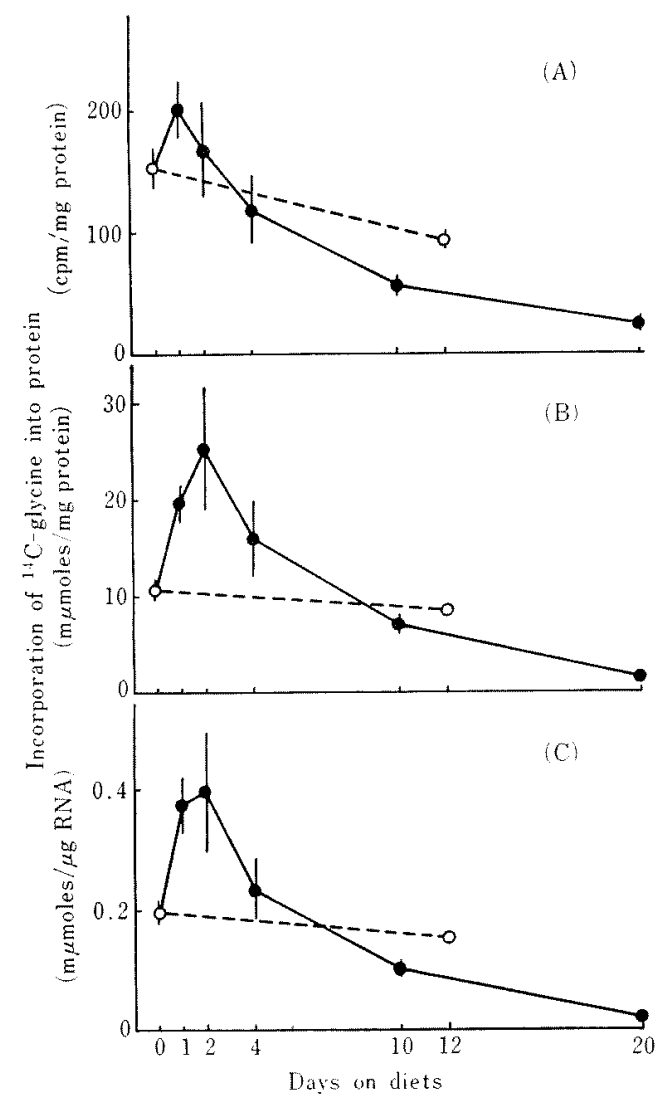

FIG. 5. Incorporation of ${ }^{14} \mathrm{C}$-Glycine into Protein

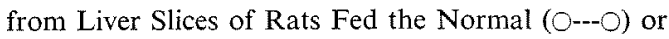
Protein-free Diet

Values in (B) and $(C)$ are calculated from values in (A) using the formulae shown in MATERIALS AND METHODS. Each point is the mean for 4 to 5 rats. The vertical bars indicate standard errors.

wards began to fall to $35 \%$ and $15 \%$ of the initial control on the 10th and 20th day respectively. When the incorporation value was corrected, the relative incorporation value in depleted rats in respect to the control rats was generally greater than before the correction. The incorporation on the 1 st and 2 nd day showed an increase of $80 \%$ and $140 \%$ respectively over the control and it dropped to 70 and $15 \%$ of the control on the 10 th and 20 th day respectively. Almost the same observation was made concerning the incorporation per unit of RNA. After 12 days on the normal diet, the incorporation of radioactivity showed a decrease of $40 \%$, but the corrected values of incorporation per unit of RNA and protein were not altered greatly. From the above, it appears that the protein synthesis capacity of the liver increased at the early stage of protein depletion but declined during prolonged depletion and was reduced greatly by the severe depletion, and that these alterations were mainly due to changes on the rate of protein synthesis per unit of RNA.

\section{DISCUSSION}

So far, it has generally been considered that the metabolism of muscle protein is relatively slow in response to dietary alterations as compared with that of liver protein: However, the present study has shown that muscle protein synthesis is reduced greaty and quickly by dietary protein deprivation. In our previous works, ${ }^{20,24}$ it was reported that muscle protein synthesis in mature adult rats, which changed little on a protein-free diet, was increased temporarily at the time of refeeding of the normal diet, and that, in muscle of rats which received daily spaced feeding, protein synthesis decreased with time after the last meal. Based on these facts, it was suggested that the role of muscle protein was highly important in protein metabolism of the whole body not only because it makes up a larger part of the body protein but also because of the wide fluctuation and quick response to alterations in the dietary conditions.

There have been some reports ${ }^{2,3,6)}$ in which muscle protein synthesis was reduced by dietary protein deficiency in in vivo experiments. However, no decrease as great as that shown in our study has been observed in any studies. Waterlow and Stephen ${ }^{3)}$ showed that the synthesis rate of muscle protein measured by continuous infusion of ${ }^{14} \mathrm{C}$-lysine fell to about $60 \%$ of the control after 3 days on protein-free diet or after 5 weeks on low protein diet. This result rather resembles our results. In an in vitro study, Young and Alexis ${ }^{16)}$ showed that protein synthesis activity of skeletal muscle ribosomes in young rats fed a low protein diet dropped to half of the initial control after 6 to 30 days. Decken and Omstedt ${ }^{17}$ reported 
that muscle ribosome activity was hardly impaired after 1 to 3 days feeding of a proteinfree diet, and showed a significant difference in activity after 4 to 6 days. Our result that the activity of ${ }^{14} \mathrm{C}$-glycine incorporation per unit of RNA was reduced to half after more than 4 days feeding of a protein-free diet, agrees well with the result of Young and Alexis, and this agreement means that the decrease in the rate of protein synthesis per unit of RNA in cells can be attributed to a fall in activity of the ribosomes themselves rather than changes in soluble fraction activity.

Protein content of the soleus muscle was reduced sharply during the first 4 days of protern depletion and then decreased gradually (Fig. 2 B). Protein synthesis in the soleus muscle decreased in a pattern similar to that for protein content (Fig. 4). This indicates that the immediate decrease in protein content of muscle in the early stages of depletion was brought about by the sudden decrease in the protein synthesis rate, followed by a delayed lowering of the catabolic rate. After the 4th day, the slight difference between the synthesis and catabolic rates is maintained. The decline of protein content by this kind of alteration in synthesis and catabolic rates has been observed in plasma albumin. ${ }^{28)}$

Concerning the influence of protein deprivation on the turnover rate of liver protein, various incompatible results have been obtained both in vivo and in vitro. In the present study, the protein synthesis increased before the 4th day of depletion and decreased after the 10th day. We pointed out in the previous report $^{24}$ that the effect of depletion varied with time after the meal. Therefore, it can generally be said that, in young adult rats fed a proteinfree diet ad libitum, protein synthesis capacity of the liver is increased early in the depletion and decreased with prolonged depletion, and that this may change under such conditions as fasting and may differ from the case of a low protein diet. We suppose that the time at which the protein synthesis rate shifts from an increase to a decrease varies widely with the animal's age.
Our previous study ${ }^{20)}$ showed that in the case of mature adult rats weighing about $400 \mathrm{~g}$ fed the protein-free diet for 7 and 16 days, almost no effect of protein depletion was observed in muscle, and protein synthesis in the liver increased although it dropped on the 16 th day to a level below that on the 7 th day. This discrepancy in the influence of protein depletion between the previous and present experiment is considered to be caused by the difference in the age of the animals.

From the changes with time of protein synthesis in muscle and the liver after feeding the protein-free diet, we believe that different patterns of adaptive response to protein depletion occurred in both early and prolonged depletion in connection with protein metabolism in rats. In the early stages of depletion, the first adaptation in which protein synthesis in muscle continues to fall rapidly but rises in the liver is revealed. It is assumed that, with a sudden alteration of any dietary condition, the liver shows a higher turnover rate of protein as a whole and becomes temporarily activated and changeable in order to replace the metabolic pattern with a new one adapted to the new dietary condition. Prolonged depletion brings on the second pattern of adaptation in which the rate of protein synthesis in mucle ceases to fall rapidly and reaches a constant value, whereas it begins to drop in the liver and cotinues to do so. In the first adaptive metabolism, protein metabolism in the liver may be more important in maintaining the regulatory functions of the body. In the second adaptation, protein metabolism in muscle seems to become more important for survival.

\section{REFERENCES}

1) M. Haider and H. Tarver, J. Nutr., 99, 433 (1970).

2) J. C. Waterlow and J. M. L. Stephen, Brit. J. Nutr., 20, 461 (1966).

3) J. C. Waterlow and J. M. L. Stephen, Clin. Sci, 35, 287 (1968).

4) J. M. L. Stephen and J. C. Waterlow, Nature, 211, 978 (1966).

5) S. Gaetani, A. Mariani, M. A. Spadoni and G. 
Tomassi, Boll. Soc, ital. Biol. sper., 37, 1685(1961).

6) D. L. Millward, Clin. Sci., 39, 591 (1970).

7) R. T. Schimke, J. Biol. Chem., 239, 3808 (1964).

8) P. R. Dallman and E. C. Manies, J. Nutr., 103, 257 (1973).

9) D. Picou and T. Taylor-Roberts, Clin. Sci., 36, 283 (1969).

10) P. Mandel, C. Quirin, M. Bloch and M. Jacob, Life Sci., 5, 325 (1966).

11) C. Chaw and L. C. Fillios, J. Nutr., 96, 327 (1968).

12) R. W. Wannemacher, Jr., W. K. Cooper and M. B. Yatvin, Biochem. $J ., 107,615$ (1968).

13) R. W. Wannemacher, Jr., C. F. Wannemacher and M. B. Yatvin, ibid., 124, 385, (1971).

14) C. O. Enwonwu and L. M. Sreebny, J. Nutr., 101, 501 (1971).

15) H. Sidransky and H. Verney, ibid., 101, 1153 (1971).

16) V. R. Young and S. D. Alexis, ibid., 96, 255(1968).

17) A. Decken and P. T. Omstedt, ibid., 100, 623 (1970).

18) S. Isaka and A. Shibata, Kagaku no Ryoiki, 13, 164 (1954).
19) W. W. Umbreit, R. H. Burris and J. F. Staffer, "Manometric Techniques and Tissue Metabolism," 2nd ed., Burgess Publishing Co., Mineapolis, 1949, p. 119.

20) A. Goto and M. Kametaka, Nippon Nögeikagaku Kaishi, 47, 37 (1973).

21) D. M. Kipnis and C. F. Cori, J. Biol. Chem., 224, 681 (1957).

22) R. C. Hider, F. B. Fern and D. L. London, BioChem. J., 114, 171 (1969).

23) G. E. Mortimore and C. E. Mondon, J. Biol. Chem., 245, 2375 (1970).

24) A. Goto and M. Kametaka, Nippon Nögeikagaku Kaishi, 47, 135 (1973).

25) W. C. Schneider, J. Biol. Chem., 161, 293 (1945).

26) S. E. Kerr and K. Seraidarian, J. Biol. Chem., 159, 211 (1945).

27) R. W. Wannemacher, Jr. and J. B. Allison, "Protein Nutrition and Free Amino Acid Patterns," ed. by J. H. Leathem, University of Tokyo Press, Tokyo, 1969, p. 206.

28) R. Kirsch, L. Frith, E. Black and R. Hoffenberg, Nature, 217, 578 (1968). 